\title{
12 How to institutionalize sustainability?
}

\author{
Analyzing the enforcement of \\ reparación integral and environmental \\ law in the hydrocarbon sector in \\ Ecuador
}

\author{
Teresa Bornschlegl
}

\section{Introduction}

Andean countries have long based their economies on the export of their natural resources. Nevertheless, the income generated through the rents from resource extraction has historically not translated into the improvement of the life quality and well-being for their wider population. On the contrary, natural resource extraction in the Andean countries went along with significant ecological degradation, violent conflicts, high poverty rates, social inequalities, and the dispossession of local communities. Historically, only a narrow group of elites has benefited from resource rents. Academic and policy literature commonly explain the reasons for this with a phenomenon called the resource curse, "the perverse effects of a country's natural resource wealth on its economic, social, or political well-being" (Ross, 2015, p. 240). Countries that depend on resource extraction lack the institutions necessary to avoid such adverse effects. The building of such institutions is hindered because "[r]esource cursed governments tend to manage natural resources opportunistically rather than strategically. Resource depletion, therefore, tends not to serve the public interest and instead consolidates wealth among a very narrow class of bureaucrats and managers" (Sovacool, 2010, p. 229). Resource-cursed countries are thus stuck in a vicious cycle: building public institutions that would put a check on elites in power would need to rely on precisely those public institutions that were previously built to serve primarily the interests of those same elites.

Two developments at the onset of the 21st century gave a new stimulus to the question of whether natural resource extraction can help countries to transition toward a more socially and ecologically just economy-a post-extractivist economy that has overcome the adverse effects of the resource curse. First, an increase in global prices for raw materials led to a new resource boom from early 2000 onward to approximately 2014. Secondly, some countries in Latin America that experienced a Left Turn sought to establish a post-neoliberal development model in which a strong state would end the social and environmental 
problems that the neoliberal development model had caused. They oriented this post-neoliberal development model around the slogan extracting for escaping extractivism, which entailed the (re)-nationalization of natural resources to invest the revenues gained in welfare programs, poverty reduction, education, health, economic diversification, and environmental protection. Accordingly, these progressive governments established several institutional innovations in governing the extractive sector that would guarantee a more socially and ecologically just distribution of the benefits and costs of resource extraction. These institutional innovations were often pushed for by social, environmental, and indigenous movements and aimed at solving the problems typically associated with resource extraction, and thus at escaping the resource curse. Designed to prevent and fully repair environmental and social damages, these institutional innovations were meant to contribute as a first step to a transition toward a post-extractivist economy.

However, the initial optimism that these progressive governments could help advance real transformation toward socially and ecologically more just economies soon vanished. The expansion of extraction led to even more dependence on resource extraction, socio-ecological conflicts, and dispossession of communal lands; corruption scandals surfaced, and falling global prices for raw materials diminished the capacity of government expenditures. Scholars have examined why the problems associated with the resource curse led, once more, to adverse outcomes, concentrating their analysis on social and economic policies. There is comparatively little analysis, however, on the institutional innovations in the environmental realm. How did they fare during the boom-and-bust cycle? Did they deliver to some extent what they promised or not? What constraints did they face, and how to explain these constraints?

This chapter explores these questions, taking Ecuador as a case study. Ecuador's Constitution Montecristi was adopted in 2008 and is one of the most famous examples of such institutional innovation, as it was the first country to integrate the Rights of Nature as a constitutional provision. This chapter asks to what extent this institutional innovation provided for better enforcement of environmental laws in the hydrocarbon sector. Specifically, it examines the Program of Environmental and Social Reparation (Programa de Reparación Ambiental y Social, PRAS) at the Ecuadorian Ministry of Environment and its enforcement of reparación integral (integral reparation), a concept derived from the Constitution Montecristi. How did PRAS perform? To what extent could state officials working at PRAS enforce the concept of reparación integral in the hydrocarbon sector? What were the most critical constraints that they encountered? This chapter answers these questions through an institutional ethnography of PRAS - following the argument that the complexity of institutional dynamics in the context of resource extraction demands a more qualitative and fine-grained approach than that provided by most resource curse research (Gilberthorpe \& Papyrakis, 2015; Gilberthorpe \& Rajak, 2016; Peters, 2016; Dargent et al., 2017; Bornschlegl, 2018). This chapter draws on qualitative and quantitative data collected during fieldwork in Ecuador over the years 
2013-2018. Quantitative data comprise a database provided by the Ministry of Environment on recorded sources of contamination and the state of the cleanup until the year 2018. Qualitative data comprise 103 interviews with representatives at different entities at national and sub-national levels as well as official documents. Interviews were carried with, for instance, representatives at the Ministry of Environment, the Ombudsman, the Comptroller General, the National Assembly, environmental departments at the provincial government, the secretary of water, the regulatory agency of water, environmental consultancies, laboratories, oil companies, local communities, NGOs, indigenous organizations, ecological and environmental scientists, petroleum engineers, and environmental lawyers. Official documents include the project reports of the three different cleanup projects, Proyecto: Eliminación de Piscinas contaminadas y limpieza de derrames en el Distrito Amazónico (PEPDA) (Petroproducción, 2008), Plan de Restauración Integral de Pasivos Ambientales en el Distrito Amazónico (PRIPA) (Petroecuador EP, 2012), and Amazonía Viva (Petroamazonas EP, 2013), of the public oil company, as well as methodological guidelines from PRAS (PRAS, 2015).

The chapter proceeds as follows: The first section presents the conceptual framework of the relationship between resource extraction, institutions, and the Left Turn. The second section describes the empirical results from the case study examining the enforcement of reparación integral, and the last section draws the main conclusions and reflects on the importance of building a specific type of institutions, namely progressive public institutions, and equipping them with sufficient, capacity, autonomy, and executive power in a sustainable way.

\section{The resource boom and institutions: the Left Turn}

The insight that the existence of functioning institutions is a necessary condition for escaping the resource curse has become a staple in research on resource extraction and the resource curse (Papyrakis, 2017). Of particular importance for avoiding the resource curse are institutions that guarantee a socially and ecologically just distribution of the benefits and costs of resource extraction. However, institutional frameworks (or the absence thereof) in resource-rich countries tend to be a reflection of the interests of those in power and the deals they make (Poteete, 2009; Bebbington et al., 2018). That is, resource-rich countries are stuck in a vicious cycle: building institutions that guarantee a socially and ecologically just distribution of the benefits and costs of extraction would require that such institutions had already been built.

The resource boom at the onset of the 21st century re-opened the question as to whether that vicious cycle could ever be overcome (Dargent et al., 2017; Addison \& Roe, 2018). Especially the governments that were part of the Left Turn in Latin America received much attention in that renewed debate. Not only did these self-defined progressive governments seek to install a whole range of institutional innovations aimed at guaranteeing a socially and ecologically just distribution of the benefits and costs of resource extraction, but they also promised to 
re-invest extractive revenues in the implementation of these institutional innovations (Burchardt \& Dietz, 2014; Burchardt et al. 2016; Broad \& Fischer-Mackey, 2017). These institutional innovations were also unique in the sense they resulted from indigenous, environmental, and social movements that had pushed for them over decades. Ecuador's Constitution Montecristi 2008 and the constitutional enshrinement of the Rights of Nature (Gudynas, 2011, 2013) counts as an example for such institutional innovations. The fact that these institutional innovations resulted from decades of mobilization of social movements also provided input to the debate on the relationship between state institutions and social change. The question became: "what type of institutions can give durability to the achievements of social movements, that, without any type of institutionalization, without any form of fixation in time, would simply vanish, as had happened many times before" (Lang \& Brand, 2015, p. 24, author's translation).

At first, the post-neoliberal development model combined with the resource boom led to an improvement in social and economic indicators, a decrease in poverty and extreme poverty, and better access to social services of the wider population. However, soon enough, it became clear that the government administrations did not advance a transition toward a more socially and ecologically just economy as the movements who had helped it to power had wanted (Cori \& Monni, 2014; de Castro et al., 2016). That is, the progressive governments failed at re-investing the extractive revenues in economic diversification, and at visibly improving the quality or quantity of employment (Gudynas, 2010, 2013; Brand et al., 2016). The progressive governments did not bring about an agrarian reform that would improve the distribution of land nor a tax reform that would make the wealthy part of the population pay their share (Burchardt et al., 2016; Veltmeyer \& Petras, 2014, 2019). The extractive frontier expanded in a way that de-industrialized the economy, increased socio-ecological conflicts, deepened ecological degradation, and further dispossessed local communities (Andreucci \& Radhuber, 2017; Villalba-Eguiluz \& Etxano, 2017; Lu et al., 2017; Svampa, 2017, 2019). Social relations remained ordered along the lines of patriarchy, classism, colonialism, just as in neoliberal times - a social transformation that would have changed the distribution of the privileges of those in power did not occur (Acosta \& Iturralde, 2013; Bull \& Aguilar-Støen, 2015; Bebbington et al., 2018). Why did the post-neoliberal development model combined with the resource boom fail to escape the resource curse? Some scholars argue that this would be so because "entrenched elites have hindered structural transformations towards an environmental governance that ensures more sustainable and equitable production" (Bull \& Aguilar-Støen, 2016, p. 139). Or, as Ospina Peralta (2012, p. 129) put it:

Why did it turn out so difficult for them [the progressive governments] to achieve any sowing after having reaped so many dollars? For the simple reason that those economic activities not only leave money in the pockets but also knit structures of power. 


\section{Teresa Bornschlegl}

While scholars provided useful insights regarding the question of why postneoliberal governments and their economic strategies failed, less disaggregated, empirically based analysis exists on what precisely happened with the institutional innovations in the environmental realm. What were the exact processes that kept those institutional innovations from developing more force? This chapter focuses on the program of Social and Environmental Reparation (PRAS) at the Ecuadorian Ministry of Environment, and its implementation of reparación integral (integral reparation) in the hydrocarbon sector. The concept of reparación integral derived directly from the Constitution Montecristi and meant to translate the constitutional provisions for environmental and social rights into public policy and practice. A reparación integral did not mean just remediating environmental damages, but to restitute the social and environmental rights and dignity of affected communities and nature and to guarantee the non-repetition of the damage. Reparación integral is thus akin of the mechanism of reparations for victims of human right violations as conceptualized by the United Nations, which comprises a guarantee for restitution, compensation, rehabilitation, satisfaction, and non-repetition to the victims of the violation (UN General Assembly, 2005). It is fair to say that one can consider the constitutional premise that one should repair damages integrally as a progressive innovation with the potential to advance pathways toward a socially and ecologically more just economy:

Here are some rough ideas still based in the field of conventional economics, from which one would need to construct the post-extractivist transition as a base for a new economy, one that we could define as an economy of Buen Vivir. To achieve this, it is necessary to deploy strategies that allow transitioning while still extracting-but less and less - the natural resources that carry the resource curse with them. . . The task is not to simply extract more natural resources for obtaining income that helps to overcome extractivism. One instead needs to optimize extraction without causing further environmental and social damage, including trying to repair and even restore the damage caused.

(Acosta, 2017, p. 10, author's translation \& emphasis)

The subsequent section presents empirical results on the performance and limitations of reparación integral in environmental law enforcement.

\section{Limits to reparación integral and environmental law enforcement}

\section{Reparación integral and the history of oil extraction}

The Ecuadorian environmental regulation defines reparación integral as:

A set of actions, processes, and measures, which . . . tend to reverse environmental and social damages and liabilities, by restoring quality, dynamics, 
ecological balance, cycles vital, structure, functioning and evolutionary process of the affected ecosystems; as well as measures and actions to facilitate the restoration of the rights of affected individuals and communities, through actions of compensation and indemnification, rehabilitation and through measures that guarantee the non-repetition and prevention of the recurrence of the damage. Reparation in the social field implies that persons, families, communities or villages affected by a negative environmental impact or environmental damage can return to living conditions and quality of life in dignity.

(Texto Unificado Legislación Ambiental Secundaria, 2015 , p. 8 [author's translation])

Integrating reparación integral in the legal framework can be interpreted as a reaction to the history of oil extraction in Ecuador and the severe damage that the oil industry had left behind, especially in its Amazon region. The extraction of oil involves toxic substances from the extracted material itself or the materials added in the process of extraction (Di Toro et al., 2007). Thus, production waste and spills - if not handled appropriately — can lead to the contamination of groundwater and surface water, sediment, and soils, and thus degrading ecosystems and negatively affecting human health (San-Sebastián \& Hurtig, 2004). If wastes and spills are abandoned in the site without proper treatment, they remain constant sources of contamination - which is what the Ecuadorian legislation defines as pasivo ambiental (COA, Art. 807). According to the Ministry of Environment, oil companies left behind 3,877 such sites in all Ecuador (PRAS, 2018). As a state official put it:

The biggest challenge of the state is at the moment to understand how we can repair the damage done to the Amazon, especially in Orellana and Sucumbíos. I think the damage goes beyond what you can imagine, and whatever number we could put on it-it is incalculable, and so still we do not fully understand or dimension the reality of that damage. What we know is that people are still dying; we know that the ecosystem will take a long, long time to recover, and for now, we do not have much clarity where even to start, it is an incredible job, and it is very costly. The biggest challenge in this country when it comes to hydrocarbons is to solve the problem with environmental and social damages that were never repaired.

(Government official [Interview], 2015)

Reparación integral aimed at repairing the damage done to the Amazon and at preventing occurrence of such damage ever again in the future. That also included preventing oil companies from compensating for environmental damages in a way that is not proportionate to the actual dimension of the damage.

It is interesting to note how [oil] companies have taken over functions of the state, how they have built roads, water systems, huts, and some public 
health infrastructure. However, all these means were rather a palliative measure for the actual damage and in no way addressed the environmental damage in an integral way.

(Government Official [Interview], 2015)

Thus, reparación integral aimed at addressing the problems that emerged from dealing with environmental damages in the past.

\section{The program of social and environmental reparation (PRAS)}

A unique entity was created in 2008 at the Ministry of Environment: the Program of Social and Environmental Reparation (PRAS) to put reparación integral into practice. PRAS's mission was to "guarantee the reparación integral for environmental damages [caused by the inadequate management of economic activities] to contribute to the improvement of the quality of life of all Ecuadorians and the protection of the Rights of Nature" (Programa de Reparación Ambiental y Social, n.d., [author's translation]). To ensure the implementation of reparación integral across different economic sectors, PRAS has several different lines of work. First, PRAS curates an information system for socio-ecological liabilities. One of PRAS's main projects in its early years was to generate a database - called "Sistema de Indicadores Ambientales y Sociales (SIPAS)" - that aimed to register all existing pasivos ambientales in the oil and gas sector. Secondly, to study how to best carry out a reparación integral, PRAS develops pilot projects in zones identified as being the most affected by environmental damages. Third, PRAS develops methodologies and guidelines, mostly derived from their pilot projects, on how to measure damages in ecological and social terms, and what activities are subsequently required on the part of the industry to repair such damages. Fourth, PRAS assesses the plans of reparación integral that the industry must submit when it causes environmental damages. Lastly, PRAS is responsible for monitoring the process of reparación integral in situ, verifying the reparación integral of environmental damages in the field. The Department of Environmental Control at the Ministry of Environment oversees the laboratory results from the samples taken from the site where environmental damage occurred. It authorizes the completion of the remediation process, once the operator has complied with the environmental regulations. A decade after the creation of PRAS, the questions arise: How did PRAS perform? Did PRAS deliver on its promise to guarantee a reparación integral of the damages caused in the Ecuadorian Amazon? What are the most critical constraints that PRAS encountered?

\section{Limits to PRAS and the enforcement of reparación integral}

The following section presents the limits to the enforcement of reparación integral, exemplified through the interactions between PRAS and the cleanup project of the public oil company. In 2002 the public oil company (then Petroproducción, today Petroamazonas EP) initiated a cleanup project called Project to eliminate contaminated ditches and clean-up of oil spills in the Amazon District (PEPDA). After 2008, PEPDA had to adjust its operation to incorporate all dimensions of 
reparación integral. First, PRAS could not get the public oil company to adopt the concept of reparación integral consistently- to repair not only the environment but also the economic, social, and cultural damages. The high costs that the implementation of reparación integral translated into the watering down of the concept on the part of the public oil company. Before 2008, the sectorial regulation employed the term reparation as synonymous with remediation-reparation meant remediating contaminated soil, piscinas (large ditches), and oil spills in which more than five barrels were spilled (Reglamento Ambiental para las Operaciones Hidrocarburifferas en el Ecuador, 2010, Art. 16). After 2008, however, all remediation procedures had to incorporate the concept of reparación integral, which meant to beyond cleaning up soils. To "align the project with the new framework of the Ministry of Environment" (Petroecuador EP, 2012, p. 10), the public oil company integrated the concept of reparación integral into its cleanup projects in 2010. PEPDA subsequently became PRIPA, the Plan of the Integral Restoration of Pasivos Ambientales (PRIPA). PRIPA included not only measures for remediating soils, but also for restoring the social rights and the dignity of affected communities. However, with the split of the state oil firm into Petroecuador EP and Petroamazonas EP in 2013, the project was again re-conceived, operating from 2013 onwards under the name Amazonía Viva (Amazon Alive). The significant difference between PRIPA and Amazonía Viva was the re-definition of reparación integral as "environmental rehabilitation" while no longer including the restitution of social rights in the new project design. The project design of Amazonía Viva abandoned the social dimension, including the compensation, indemnification, and satisfaction of affected people and communities. Interviewees at Amazonía Viva said that this would not mean that Petroamazonas EP would not pay compensation and indemnification to affected persons and communities at all. It only meant that this did not fall into the scope of the project of Amazonía Viva anymore that only included the remediation of soils. While the Vice-presidency endorsed Amazonía Viva, which meant that it would receive priority status in the national budget allocation, interviewees nevertheless expressed concerns in 2015 that the budget for the project would shrink with falling oil prices. One can thus assume the change in the adoption of reparacion integral had likely to do with the uncertainty of how much money would even be required on the part of Petroamazonas EP to fulfill the compensation and indemnification requirements. So reparación integral shifted back from restoring rights to remediating soils.

The fact that the restitution of rights was no longer part of the cleanup project generated mistrust and conflicts among communities. Some community members did not want the damage in their territory to be cleaned up because they feared that then they would have no evidence that they also had a right to be compensatedeither financially or with a collective good. Therefore, they often refused entry on to their property, which, in turn, inhibited the clean-up from taking place:

People do not like that the pasivos get cleaned up as they fear that then they have no evidence anymore for receiving any compensation or indemnification.

(Government official [Interview], 2016) 
It remains unclear how and when Petroamazonas would start to compensate and indemnify affected people and communities for the pasivos ambientales. Community members also expressed concern about not being asked or even informed about how they would like the cleanup to take place, and that local social organizations would, unfortunately, have no say in the cleanup operations (Activist [Interview], 2018).

Second, even if focusing only on remediating soils, the cleanup process advances only very slowly "at the speed of a turtle" (Government official [Interview], 2015). PRAS registers 3,877 pasivos in all regions in Ecuador. Between 2005 and 2018, 1,488 pasivos were cleaned up, leaving 2,389 that still need to be dealt with in the years to come. That would mean that it would take more than 20 years to finish all cleanups in Ecuador-only remediating soils. According to the PRAS database, more fosas (small ditches) than piscinas (big ditches) were cleaned up over the years. Interviewees indicated that fosas were prioritized as they might be easier to remediate and thus lead more quickly to successful results. That means that remediating the outstanding piscinas will likely take even longer than the time it took to remediate fosas.

Additionally, old damage continues to be discovered, and new damage continues to be produced. The growing number of contamination sources is visible in the project reports-PEPDA indicated 1,420 sources of contamination in the Ecuadorian Amazon while Amazonía Viva indicates 2,550 (Petroamazonas EP, 2018). Likewise, the PRAS database from the year 2016 indicated a total of 3,658 pasivos ambientales, while the database from 2018 counted 3,877 (Bornschlegl, 2017; PRAS, 2018). As an interviewee said: "It will already take easily 10 to 15 years to remediate the damage that exists, and that alone if there would be no new pasivos produced. However, new pasivos continue to be produced all the time" (Corporate representative [Interview], 2015). The reason for this is that oil companies rarely replace those old infrastructures that generated most of the damages in the first place. Interviewees across the board say that it remains cheaper for the industry to pay the administrative fine for the environmental damage than to invest in new infrastructure. Some extraction sites are said to produce a spill almost daily (Government official [Interview], 2015).

These limits to reparación integral and the enforcement of environmental law, in turn, limit the possibilities for economic diversification in the regions in which extraction takes place.

The challenge is for us to have a region without contamination, and that a new productive sector can be created. The oil will disappear; the oil will end one day. However, if they [the oil companies] leave us contaminated with pasivos, for what do these rivers serve? For nothing. However, if they remediate, if they leave this region clean, that could be the start of a new productive activity, such as tourism. Here we have a great potential for tourism.

(Government official [Interview], 2015) 
Environmental damages are a threat to alternative economic sectors such as agriculture and tourism, specifically eco-tourism. If all that is left are degraded landscapes, there will not be many alternative economic sectors that could generate state revenues after resource depletion (Larrea, 2017). That is, economic diversification through sectors such as agriculture and tourism continue to be made impossible through environmental degradation (Perreault, 2013; Cuba et al., 2014). Instead of investing in the upgrading of mature sites, the extractive frontier expands, opening more and more new sites (Kaup, 2010).

\section{Conclusion}

The resource boom, as well as the Left Turn in Latin America, has brought new fodder to the question of whether natural resources can overcome the resource curse and finally lead to a socially and ecologically just development. Scholars examining the performance of progressive governments in the context of the resource boom have demonstrated their failure in bringing about any substantial structural transformation. This chapter found that institutional innovations were, however, established that could have contributed to advance a transformation away from extractivism, but did not. Taking reparación integral and its enforcement as example, this chapter has shown that insufficient funding and a lack of executive power did constrain the reach of these institutional innovations - constraints that are common explanations for the chronic weakness of environmental law enforcement.

There are several implications of these findings for research that examines institutional dynamics in the context of resource extraction, specifically for those working on the politics of institutions in the resource curse framework. In line with the argument of this book and others who have argued that institutions is too coarse of a term for adding to the understanding of the resource curse, this chapter maintains that further research should specifically study the trajectories of institutions that could be called progressive public institutions. It would be especially essential to replace the focus of which institutions lead to economic growth with the inquiry of which institutions serve the advancement of socially and ecologically just economies, as conceptualized by ecological economists. As North et al. (2017, p. 78) argue:

In countries with entrenched traditions of mining and hydrocarbon extraction, such as Bolivia and Peru, just leaving the stuff under the ground altogether is not realistic. Still, diversifying and shifting the balance of policies away from extraction and towards policies of employment generation and economic diversification, as described above, may bring about substantial social and economic advance.

For instance, why is there no sweeping tax reform? Why is there no sweeping agrarian reform? Some scholars have already laid the groundwork for this to be 
built upon (Alayza \& Gudynas, 2011; Gudynas, 2013; Escobar, 2015; Acosta \& Brand, 2017).

Thus, it would be essential to study how to build and sustain progressive institutions over time and across space. Further research could provide cross-national, longitudinal comparative in-depth analysis to questions as to how institutional innovations that critically confront extractivism could gain more traction in real politics, and how to translate economic alternatives to extractivism into political options that gain wider public acceptance (Peters, 2016). In doing so, one could focus, on the one hand, on political alliances and political capture. Who exactly obstructs institutional innovations from developing teeth, what channels of influence do they use, and what narratives and networks do they mobilize? One can build on research that has studied political capture and lobbying in the context of resource extraction (Crabtree \& Durand, 2017; Bebbington et al., 2018), and research that has examined cases such as the tobacco industry (Kessler, 2001), and climate change denial (Oreskes \& Conway, 2010). On the other hand, further research could examine why and how social mobilization can make progressive institutions gain wider public acceptance and political traction (Ospina Peralta et al., 2015). As Arendt (1969, p. 41) put it: "All political institutions are manifestations and materializations of power; they petrify and decay as soon as the living power of the people ceases to uphold them".

\section{References}

Acosta, A. (2017). Posextractivismo: Del discurso a la práctica-Reflexiones para la acción. International Development Policy | Revue Internationale de Politique de Développement, 9, 1-20. https://doi.org/10.4000/poldev.2496

Acosta, A., \& Brand, U. (2017). Salidas del laberinto capitalista. Decrecimiento y postextractivismo. Fundación Rosa Luxemburgo.

Acosta Ruiz, M., \& Iturralde, P. (2013). La alquimia de la riqueza. Estado, petróleo, y patrón de acumulación en Ecuador. Centro de Derechos Económicos y Sociales (CDES). ISBN: 978-9978-334-06-5

Addison, T., \& Roe, A. (2018). Extractive industries. The management of resources as driver of sustainable development. Oxford University Press. https://doi.org/10.1093/ oso/9780198817369.001.0001

Alayza, A., \& Gudynas, E. (Eds.). (2011). Transiciones. Postextractivismo y alternativas al extractivismo en el Perú. RedGe, CEPES. ISBN: 978-9972-722-19-6

Andreucci, D., \& Radhuber, I. M. (2017). Limits to "counter-neoliberal" reform: Mining expansion and the marginalization of post-extractivist forces in Evo Morales's Bolivia. Geoforum, 84, 280-291. https://doi.org/10.1016/j.geoforum.2015.09.002

Arendt, H. (1969). On violence. Harcourt Brace Jovanovich Publishers.

Bebbington, A., Abdulai, A.-G., Humphreys Bebbington, D., Hinfelaar, M., \& Sandborn, C. (Eds.). (2018). Governing extractive industries. Politics, histories, ideas. Oxford University Press. https://doi.org/10.1093/oso/9780198820932.001.0001

Bornschlegl, T. (2017). Three snapshots into complexity. A political ecological analysis of the regulatory enforcement of environmental laws in the oil and gas sector in Ecuador [Ph.D.-thesis]. Graduate School of Geography, Clark University. 
Bornschlegl, T. (2018). Petro-geographies and the dialectic of the everyday. Enforcing environmental laws in the hydrocarbon sector in post-neoliberal Ecuador. Journal of Latin American Geography, 17(3), 15-42. https://doi.org/10.1353/lag.2018.0040

Brand, U., Dietz, K., \& Lang, M. (2016). Neo-extractivism in Latin America. One side of a new phase of global capitalist dynamics. Ciencia Política, 11(21), 125-159.

Broad, R., \& Fischer-Mackey, J. (2017). From extractivism towards buen vivir: Mining policy as an indicator of a new development paradigm prioritizing the environment. Third World Quarterly, 38(6), 1327-1349. https://doi.org/10.1080/01436597.2016.1262741

Bull, B., \& Aguilar-Støen, M. (Eds.). (2015). Environmental politics in Latin America: Elite dynamics, the left tide and sustainable development. Routledge.

Bull, B., \& Aguilar-Støen, M. (2016). Changing elites, institutions and environmental governance. In F. De Castro, B. Hogenboom, \& M. Baud (Eds.), Environmental governance in Latin America (pp. 137-163). Palgrave Macmillan.

Burchardt, H. J., \& Dietz, K. (2014). (Neo-)extractivism-a new challenge for development theory from Latin America. Third World Quarterly, 35(3), 468-486. https://doi.org/10.1 080/01436597.2014.893488

Burchardt, H. J., Dominguez, R., Larrea, C., \& Peters, S. (2016). Nada dura para siempre. Neo-extractivismo tras el boom de las materias primas. Ediciones Abya-Yala. ISBN: 978-9942-14-842-1

Cori, A., \& Monni, S. (2014). The resource curse hypothesis: Evidence from Ecuador. SEEDS Working Paper Series 28.

Crabtree, J., \& Durand, F. (2017). Peru: Elite power and political capture. Zed Books. ISBN 978-1-78360-903-1

Cuba, N., Bebbington, A., Rogan, J., \& Millones, M. (2014). Extractive industries, livelihoods and natural resource competition: Mapping overlapping claims in Peru and Ghana. Applied Geography, 54, 250-261. https://doi.org/10.1016/j.apgeog.2014.05.003

Dargent, E., Orihuela, J. C., Paredes, M., \& Ulfe, M. E. (Eds.). (2017). Resource booms and institutional pathways. The case of the extractive industry in Peru. Palgrave Macmillan.

De Castro, F., Hogenboom, B., \& Baud, M. (Eds.). (2016). Environmental governance in Latin America. Palgrave Macmillan. https://doi.org/10.1057/9781137505729

Di Toro, D. M., McGrath, J. A., \& Stubblefield, W. A. (2007). Predicting the toxicity of neat and weathered crude oil: Toxic potential and the toxicity of saturated mixtures. Environmental Toxicology and Chemistry, 26(1), 24-36.

Escobar, A. (2015). Degrowth, postdevelopment, and transitions: A preliminary conversation. Sustainability Science, 10(3), 451-462.

Gilberthorpe, E., \& Papyrakis, E. (2015). The extractive industries and development: The resource curse at the micro, meso and macro levels. The Extractive Industries and Society, 2(2), 381-390. https://doi.org/10.1016/j.exis.2015.02.008

Gilberthorpe, E., \& Rajak, D. (2016). The anthropology of extraction: Critical perspectives on the resource curse. Journal of Development Studies, 53(3), 186-204. https://doi.org/10. 1080/00220388.2016.1160064

Gudynas, E. (2010). The new extractivism of the 21st century: Ten urgent theses about extractivism in relation to current South American progressivism. Center for International Policy.

Gudynas, E. (2011). Los derechos de la naturaleza en serio. In A. Acosta \& E. Martínez (Eds.), La naturaleza con derechos. De la filosofía a la política (pp. 239-287). Ediciones AbyaYala. ISBN: 978-9978-22-995-8

Gudynas, E. (2013). Transitions to post-extractivism: Directions, options, areas of action. In M. Lang \& D. Mokrani (Eds.), Beyond development: Alternative visions from Latin America (pp. 165-188). Transnational Institute. 
Kaup, B. Z. (2010). A neoliberal nationalization? The constraints on natural-gas-led development in Bolivia. Latin American perspectives, 37(3), 123-138. https://doi.org/10.1177\% 2F0094582X10366534

Kessler, D. (2001). A Question of intent: A great American battle with a deadly industry. Public Affairs.

Lang, M., \& Brand, U. (2015). Dimensiones de la transformación social y el rol de las instituciones. Introducción. In M. Lang, B. Cevallos, \& C. López (Eds.), ¿Cómo transformar? Instituciones y cambio social en América Latina y Europa (pp. 7-35). Abya-Yala. ISBN: 978-9942-09-317-2

Larrea, C. (Ed.). (2017). ¿Está agotado el período petrolero en Ecuador? Alternativas hacia una sociedad más sustentable y equitativa: un estudio multicriterio. Ediciones La Tierra. http://hdl. handle.net/10644/5812

Lu, F., Valdivia, G., \& Silva, N. (2017). Oil, revolution, and indigenous citizenship in Ecuadorian Amazonia. Palgrave Macmillan.

North, L., Grinspun, R., \& Larrea, C. (2017). Post-neoliberalism in Latin America: Continuities and discontinuities in regimes of extraction. In K. Kalowatie Deonandan \& M. Dougherty (Eds.), Mining in Latin America: Critical approaches to the new extraction (pp. 63-80). Routledge.

Oreskes, N., \& Conway, E. (2010). Merchants of doubts. How a handful of scientists obscured the truth on issues from tobacco smoke to global warming. Bloomsbury Press. ISBN: 9781596916104

Ospina Peralta, P. (2012). Promesas temporales. Cambio del régimen de acumulación en Ecuador, propuestas y realizaciones de la Revolución Ciudadana. In L. López, M. Molina, D. Pardo, J. Piedrahita, L. Rojas, N. Tejada, \& R. Zelik (Eds.), ¿Otros mundos posibles? Crisis, gobiernos progresistas, alternativas de sociedad (pp. 113-130). Fundación Rosa Luxemburgo/Universidad Nacional de Colombia. ISBN: 978-958-761-136-6

Ospina Peralta, P., Bebbington, A., Hollenstein, P., Nussbaum, I., Ramírez, E. (2015). Extraterritorial investments, environmental crisis, and collective action in Latin America. World Development, 73, 32-43. https://doi.org/10.1016/j.worlddev.2014.08.020

Papyrakis, E. (2017). The resource curse - what have we learned from two decades of intensive research: Introduction to the special issue. The Journal of Development Studies, 53(2), 175-185. https://doi.org/10.1080/00220388.2016.1160070

Perreault, T. (2013). Dispossession by accumulation? Mining, water and the nature of enclosure on the Bolivian Altiplano. Antipode, 45(5), 1050-1069.

Peters, S. (2016). Fin del ciclo: El neo-extractivismo en Suramérica frente a la caída de los precios de las materias primas. Un análisis desde una perspectiva de la teoría rentista. In H. J. Burchardt, R. Dominguez, C. Larrea, \& S. Peters (Eds.), Nada dura para siempre. Neo-extractivismo tras el boom de las materias primas (pp. 21-55). Ediciones Abya-Yala. ISBN: 978-9942-14-842-1

Petroamazonas EP. (2013). Amazonía viva: Proyecto Amazonía viva. Petroamazonas EP.

Petroamazonas EP. (2018). Memoria de gestión 2018: Proyecto Amazonía Viva. Petroamazonas EP.

Petroecuador EP. (2012). Plan de restauración integral de pasivos ambientales en el distrito Amazónico (PRIPA). Petroecuador EP.

Petroproducción. (2008). Proyecto: Eliminación de piscinas contaminadas y limpieza de derrames en el distrito Amazónico (PEPDA). Petroproducción.

Poteete, A. R. (2009). Is development path dependent or political? A reinterpretation of mineral-dependent development in Botswana. The Journal of Development, 45(4), 544-571. https://doi.org/10.1080/00220380802265488

Programa de Reparación Ambiental y Social-PRAS. (2015). Guía metodológica para la construcción de planes de reparación integral (PRI). Ministerio del Ambiente del Ecuador. 
Programa de Reparación Ambiental y Social-PRAS. (2018). Pasivos ambientales [Database]. Ministerio del Ambiente del Ecuador.

Programa de Reparación Ambiental y Social-PRAS. (n.d.). Amazonia viva/ Proceso de restauración. http://pras.ambiente.gob.ec/web/amazonia-viva

Reglamento Ambiental para las Operaciones Hidrocarburíferas en el Ecuador-RAOHE. (2010). Decreto Ejecutivo 1215. https://www.ambiente.gob.ec/wp-content/uploads/ downloads/2012/09/RAOHE-DECRETO-EJECUTIVO-1215.pdf

Ross, M. L. (2015). What have we learned about the resource curse? Annual Review of Political Science, 18, 239-259. https://doi.org/10.1146/annurev-polisci-052213-040359

San-Sebastián, M., \& Hurtig, A. K. (2004). Oil exploitation in the Amazon basin of Ecuador: A public health emergency. Revista Panamericana de Salud Pública, 15(3), 205-211. https:// doi.org/10.1590/S1020-49892004000300014

Sovacool, B. K. (2010). The political economy of oil and gas in Southeast Asia: Heading towards the natural resource curse? The Pacific Review, 23(2), 225-259.

Svampa, M. (2017). Del cambio de época al fin de ciclo. Gobiernos progresistas, extractivismo, movimientos sociales en América Latina. Edhasa.

Svampa, M. (2019). Las fronteras del neoextractivismo en América Latina. Conflictos socioambientales, giro ecoterritorial y nuevas dependencias. CALAS, Maria Sibylla Merian Center.

Texto Unificado Legislación Ambiental Secundaria, Reforma Libro VI. (2015). Acuerdo Ministerial 061. Registro Oficial Edición Especial 316 de 4 de Mayo 2015.

UN General Assembly. (2005). Resolution A/RES/60/147. Basic principles and guidelines on the right to a remedy and reparation for victims of gross violations of international human rights law and serious violations of international humanitarian law.https://www.ohchr.org/en/professionalinterest/pages/remedyandreparation.aspx

Veltmeyer, H., \& Petras, J. (2019). Latin America in the vortex of social change. Development and resistance dynamics. Routledge. https://doi.org/10.4324/9780429032042

Veltmeyer, H., \& Petras, J. (Eds.). (2014). The New extractivism. A post-neoliberal development model or imperialism of the twenty-first century? Zed Books. https://doi.org/10.1002/jid.3091

Villalba-Eguiluz, C. U., \& Etxano, I. (2017). Buen Vivir vs development (II): The limits of (neo) extractivism. Ecological Economics, 138(C), 1-11. https://doi.org/10.1016/j. ecolecon.2017.03.010 